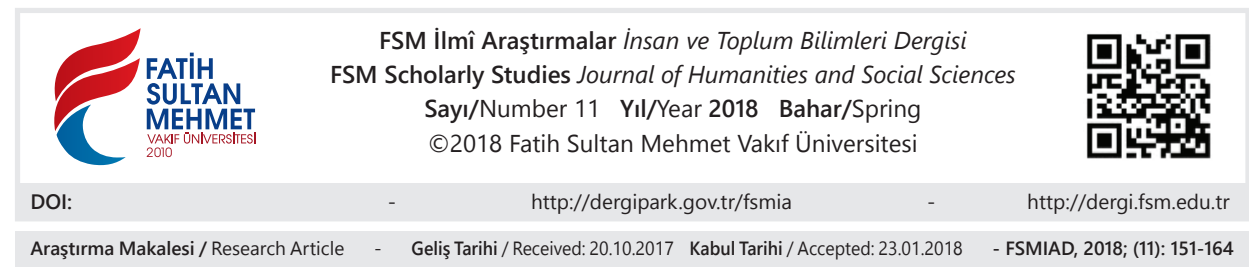

\title{
Çağrı Merkezi Hizmetleri Bölümü Öğrencilerinin Gelecek Beklentileri Üzerine Bir Araştırma: Selçuk Üniversitesi Örneği ${ }^{*}$ \\ İlknur Çevik Tekin** \\ Tahir Akgemci***
}

Öz

Bu çalışma, Selçuk Üniversitesi Sosyal Bilimler Meslek Yüksek Okulu, Çağrı Merkezi Hizmetleri Bölümü, örgün ve ikinci öğretimde öğrenim gören öğrencilerin gelecek beklentilerini ölçmeyi amaçlamaktadır. Araştırma kapsamında kullanılan anketin ilk bölümünde demografik özellikleri ölçen sorular yer almaktadır. İkinci bölümde ise Tuncer (2011)'in literatür taraması sonucu oluşturduğu 14 sorudan oluşan, öğrencilerin gelecek beklenti düzeylerini ölçen sorular bulunmaktadır. Araştırma verileri SPSS 24 istatistik programında analiz edilip, belirlenen hipotezler çerçevesinde yorumlanmıştır. Çalışma sonucunda; cinsiyete, sınıfa, öğretim durumuna, mezun olunan liseye göre anlamlı farklılık görülmemiştir. Ayrıca ailesi en az gelire sahip grubun en az beklentiye sahip grup olduğu, küçük yerleşim alanlarında yaşayan öğrencilerin, büyük yerleşim alanlarında yaşayan öğrencilere göre gelecekten beklentilerinin daha yüksek olduğu bulgulanmış-

\footnotetext{
* Bu çalışma YEAUK 2017 isimli kongrede sözlü olarak sunulmuştur.

** Öğr. Gör., Selçuk Üniversitesi Sosyal Bilimler MYO İşletme Yönetimi Bölümü, Konya/Türkiye, ilknurtekin@selcuk.edu.tr, orcid.org/0000-0002-0802-1733

*** Prof. Dr., Selçuk Üniversitesi İktisadi ve İdari Bilimler Fakültesi İşletme Bölümü, Konya/ Türkiye, takgemci@selcuk.edu.tr, orcid.org/0000-0001-5936-7462
} 
tır. Öğrencilerin kardeş sayıları arttıkça genel olarak gelecek beklentilerinin arttığı yine çalışma sonucu elde edilen istatistiki bulgular arasındadır.

Anahtar Kelimeler: Gelecek, beklenti, yüksek öğretim.

\title{
A Research on the Future Expectations of the Call Center Services Department Students: Selçuk University Sample
}

\begin{abstract}
This study aims to measure the future expectations of the students who are studying in daytime and evening education in Selcuk University Social Sciences Vocational High School, Call Center Services Department. In the first part of the questionnaire used in the survey, questions that measure demographic characteristics are included. In these condpart, Tuncer (2011) has questions that measure the future expectation levels of students, consisting of 14 questions which are the result of the literature search. The data of the research was be analyzed in SPSS 24 statistical program and interpreted within the frame work of determined hypotheses. In the results of working; There were no significant differences in terms of sex, class, teaching status, graduation grade. It was also found that the family with the least family had the least expectant group, the students living in the small residential areas had a higher expectation than the students living in the big residential areas. As the number of siblings of students increases, expectations of future increases in general are again found to be statistically significant findings.
\end{abstract}

Keywords: Future, expectation, higher education. 


\section{Giriş}

TDK'ya göre beklenti "Bireyin belli şart ve durumların alacağı biçimler veya kendisinden beklenenler konusundaki öngörüsü”dü̈r1. Gelecek, daha gerçekleşmemiş, ama bireylerin arzuları doğrultusunda yaşamayı istediği, hayatın insanlar1 hep ileriye yönelten bir bölümüdür. Bu bağlamda gelecek beklentisi bireylerin, gelecekte nasıl, nerede, kimlerle vb. olmak istemelerine bağlı olarak, bireysel ve toplumsal yaşamdan istedikleridir ${ }^{2}$. Gelecek beklentisine ilişkin öncü çalışmalar, 21. yüzyılın ilk çeyreğinde başlamış, bu yüzyılın ortalarında yeniden canlanmıştır ${ }^{3}$. Adler $(1994)^{4 ‘}$ e göre bir insanın davranışlarını geçmiş yaşantıları kadar gelecekten beklentileri de belirler. "Yaşam Amacı" insanın önündeki hedef veya yol gösteren bir 1şık gibidir. Aynı gerçek toplumlar için de geçerlidir. Toplumlar ekonomik ve sosyal politikalarıyla hedeflerini belirler, gelişim çizgisinde ona göre yol alırlar. Toplumda gençlerin geleceğe ilişkin beklentileri ise toplumun gelişim çizgisini ve dinamiğini belirleyen önemli etkenlerdendir. Çünkü gençlik, toplum için potansiyel bir güçtür. Bu noktada toplumun gelecek beklentisiyle gençlerin gelecekten beklentileri çakışmaktadır ${ }^{5}$. Bir toplumda gençlerin geleceğe ilişkin beklentileri o toplumun gelişim çizgisini ve dinamiğini belirleyen önemli etkenlerdendir ${ }^{6}$. Gelecek tasarımını iyi yapamayan ve beklentilerini gerçekleştiremeyen kişilerin yoğun bir ümitsizlik duygusu yaşaması, stresle baş başa kalması muhtemeldir. İş yaşamında stresin iş taleplerinin sonucu olarak kabul edilebilir bir yanı olmasına karşın, bireyin kendini ortaya koyma firsatı bulamaması ve bu yönde desteklenmemesi uzun süreli strese neden olarak tükenmişliğe dönüşebilmektedir. Bu halde mesleki eğitimden geçen çalışanların uygun mesleki tercihler yapmış ve geleceklerine yönelik olumlu beklentiler içinde olmaları son derece önemlidir ${ }^{7}$. Ancak insanın beklenti düzeyinin belirlenmesinde kendinden ve çev-

1 http://www.tdk.gov.tr

2 Hıdır Apak, "Suriyeli Göçmenlerin Gelecek Beklentileri”, Birey ve Toplum Sosyal Bilimler Dergisi, 5(1), 2015, s. 126.

3 Tuba Şanlı, Sinan Saraçlı, “" The Journal of KAU IIBF, 6(11), 2015, s.27. Analysis Of The Factors Effecting The University Students' Future Expectations

4 Alfred Adler, İnsan Tabiatını Tanıma. Çev. Ayda Yörükan. Ankara: Türkiye İş Bankası Yayınlar1, 1994.

5 Müzeyyen Güleri, "Üniversiteli ve İşçi Gençliğin Gelecek Beklentileri ve Kötümserlik İyimserlik Düzeyleri”. Kriz Dergisi, $1991,(1)$ 7, s. 07.

6 Müzeyyen Güleri, A.g.e, s. ${ }^{\circ}$.

7 Ömay Çokluk, Örgütlerde Tükenmişlik: Yönetimde Çağdaş Yaklaşımlar. (Edit: Cevat Elma ve Kamile Demir). 2000, Ankara: Anı Yayıncılık. Aktaran; Murat Tuncer, Yükseköğretim Gençliğinin Gelecek Beklentileri Üzerine Bir Araştırma, Turkish Studies-International Periodical for the Languages, Literature and History of Turkishor Turkic, 6(2), 2011, s.936. 
resinden gelen koşulların önemi büyüktür. Örneğin bir kişinin, sağlıklı, hasta, parlak, donuk zekâlı oluşu, tarımsal bir toplumda, şehirde veya bir metropolde yaşaması onun beklenti düzeylerini belirlemede büyük önem taşır ${ }^{8}$.

\section{Araştırmanın Amacı ve Yöntemi}

Çalışmada Çağrı Merkezi Hizmetleri bölümünde öğrenim gören öğrencilerin gelecek beklentilerini ölçmeye yönelik bir araştırma yapılmıştır. Çalışmanın evrenini Selçuk Üniversitesi Sosyal Bilimler Meslek Yüksek Okulunda 2016-2017 eğitim yılında öğrenim gören 1. ve 2. sınıf öğrenciler oluşturmaktadır. Öğrencilerin 89'u normal öğretim öğrencisi, 81'i ise ikinci öğretim öğrencisi olarak eğitim almaktadır. Çalışma kapsamında 160 öğrenciye ulaşılmış olup, örneklemi 153 öğrenci verileri (evrenin \%94'ü) oluşturmaktadır. Veriler anket yoluyla elde edilmiştir. Araştırma kapsamında kullanılan anketin ilk bölümünde demografik özellikleri ölçen sorular yer almaktadır. İkinci bölümünde ise Tuncer (2011) ${ }^{9}$ in literatür taraması sonucu oluşturduğu 14 sorudan oluşan, öğrencilerin gelecek beklenti düzeylerini ölçen sorular bulunmaktadır. Araştırma verileri SPSS 24 istatistik programında analiz edilip, belirlenen hipotezler çerçevesinde yorumlanmıştır. Araştırmanın hipotezleri:

1. Çağr1 Merkezi Hizmetleri Bölümü öğrencilerinin beklenti düzeyleri cinsiyete göre farklılık göstermektedir.

2. Çağrı Merkezi Hizmetleri Bölümü öğrencilerinin beklenti düzeyleri birinci ve ikinci sınıf olmalarına göre değişmektedir.

3. Çağrı Merkezi Hizmetleri Bölümü öğrencilerinin beklenti düzeyi normal ya da ikinci öğretim öğrenci olmalarına göre değişmektedir.

4. Çağrı Merkezi Hizmetleri Bölümü öğrencilerinin beklenti düzeyleri mezun olunan lise türüne göre değişiklik göstermektedir.

5. Çağrı Merkezi Hizmetleri Bölümü öğrencilerinin beklenti düzeyleri ailelerinin gelirine göre değişmektedir.

6. Çağrı Merkezi Hizmetleri Bölümü öğrencilerinin beklenti düzeyleri ailenin yaşadığ 1 yerleşim yerine göre değişmektedir.

7. Çağrı Merkezi Hizmetleri Bölümü öğrencilerinin beklenti düzeyleri aile ile yaşayıp yaşamadıklarına göre değişmektedir.

8. Çağnı Merkezi Hizmetleri Bölümü öğrencilerinin beklenti düzeyleri kardeş sayısına göre değişmektedir

8 Metin İnceoğlu, Güdüleme Yöntemleri, 1985, Ankara. S. 6.

9 Murat Tuncer, A.g.e. 
Araştırmanın Bulguları

Tablo 1. Demografik Özellikler

\begin{tabular}{|c|c|c|}
\hline Demografik Özellik & Sayı(n) & Yüzde (\%) \\
\hline \multicolumn{3}{|l|}{ CINSIYET } \\
\hline Bayan & 89 & 58,2 \\
\hline Erkek & 64 & 41,8 \\
\hline \multicolumn{3}{|l|}{ SINIF } \\
\hline 1. & 71 & 46,4 \\
\hline 2. & 82 & 53,6 \\
\hline \multicolumn{3}{|l|}{ ÖĞRENIM TÜRÜ } \\
\hline Normal & 80 & 52,3 \\
\hline İkinci & 73 & 47,7 \\
\hline \multicolumn{3}{|l|}{ KARDEŞ SAYISI } \\
\hline Yok & 2 & 1,3 \\
\hline 1 & 25 & 16,3 \\
\hline 2 & 38 & 24,8 \\
\hline 3 & 48 & 31,4 \\
\hline 4 ve üzeri & 40 & 26,1 \\
\hline \multicolumn{3}{|c|}{ AILLENİN YAŞADIĞI YER } \\
\hline Köy & 24 & 15,7 \\
\hline İlçe & 45 & 29,4 \\
\hline İl & 84 & 54,9 \\
\hline \multicolumn{3}{|c|}{ MEZUN OLUNAN LISSE } \\
\hline Meslek Lisesi & 75 & 49,0 \\
\hline Diğer & 78 & 51,0 \\
\hline \multicolumn{3}{|l|}{ BİRLIKKTE YAŞAM } \\
\hline Aile ile & 88 & 57,5 \\
\hline Yurt & 45 & 27,4 \\
\hline Evde (Tek) & 6 & 3,9 \\
\hline Evde (Arkadaşlarla) & 14 & 9,2 \\
\hline \multicolumn{3}{|l|}{ AİLENIN GELİRI } \\
\hline $1000-1500$ & 51 & 33,3 \\
\hline $1501-2000$ & 44 & 28,8 \\
\hline $2001-2500$ & 19 & 12,4 \\
\hline
\end{tabular}




\begin{tabular}{|l|l|l|}
\hline $2001-3000$ & 20 & 13,1 \\
\hline 3001 ve üzeri & 19 & 12,4 \\
\hline
\end{tabular}

Çağrı Merkezi Hizmetleri Bölümü öğrencilerinin demografik özellikleri Tablo 1'de gösterilmiştir. Öğrencilerin aile gelirlerinin çoğunlukla asgari ücret düzeyine yakın olması dikkat çekicidir. Programı tercih eden öğrencilerin yarıdan fazlasının kız olması yine Tablo 1'de görülmektedir. Ayrıca, öğrencilerin yarısından fazlası ilde yaşamaktadır. Ailesi ile yaşayan öğrencilerin oranı da diğerlerine göre \%50’nin üzerindedir. Çalışma yapılan üniversite yerleşkesi Konya'da olmasından dolayı öğrencilerin büyük bir kısmının Konya'da ailesiyle birlikte ikamet ettiği sonucu çıkabilir.

Tablo 2. Tanımlayıcı İstatistikler

\begin{tabular}{|l|c|c|c|}
\hline Maddeler & N & Ort. & $\begin{array}{c}\text { Std. } \\
\text { Sapma }\end{array}$ \\
\hline 1. Benimle gurur duyulacak bir meslekte çalışacağım & 153 & 3,5948 & 1,26926 \\
\hline 2. Kamu kadrosunda bir işte çalışacağım & 153 & 3,5163 & 1,31342 \\
\hline 3. Yeteneklerimi gösterebileceğim bir işte çalışacağım & 153 & 3,6536 & 1,25300 \\
\hline 4. Masa başı bir işte çalışacağım & 153 & 3,6536 & 1,29432 \\
\hline 5. Beni skmmayan bir işte çalışacağım & 153 & 3,7386 & 1,29661 \\
\hline 6. Toplumda saygı duyulan bir meslekte çalışacağım & 153 & 3,7451 & 1,26454 \\
\hline 7. Kazancı bol olan bir işte çalışacağım & 153 & 3,5294 & 1,24107 \\
\hline 8. Yükselebilme imkânı olan bir işte çalışacağım & 153 & 3,8431 & 1,17046 \\
\hline 9. Yapacağım işten zevk alacağım & 153 & 3,8627 & 1,23042 \\
\hline 10. Yapacağım iş bana lüks bir hayat sunacak & 153 & 3,1634 & 1,27454 \\
\hline 11. Yapacağım iş cinsiyetime uygun olacak & 153 & 3,7778 & 1,23129 \\
\hline 12. Yapacağım iş özel yaşamıma engel olmayacak & 153 & 3,7778 & 1,20973 \\
\hline 13. Seçeceğim meslek geleceğimi güven altına alacak & 153 & 3,7516 & 1,30425 \\
\hline $\begin{array}{l}\text { 14. Aldığım eğitimi yeterli görmeyip bir üst eğitim } \\
\text { devam edeceğim }\end{array}$ & 153 & 3,7190 & 1,23788 \\
\hline
\end{tabular}

En yüksek ortalama 3,86 ile "yaptığım işten zevk alacağım” maddesine aittir. İkinci önem verdikleri madde 3,84 ortalama ile "yükselme imkânı olan bir işte çalışacağım" maddesidir. En az katıldıkları madde 3,16 ortalama ile "yaptığım iş bana lüks bir hayat sunacak" önermesidir. Bu ortalamalara göre gençlerin yaptıkları işten zevk almaya her şeyden çok önem verdikleri ve yükselme isteklerinin oldukça önemli olduğu görülmektedir. Yaptıkları işin lüks bir hayat sunması en az beklenti gösterdikleri maddeyi oluşturmaktadır. 
Tablo 3. KMO ve Barlett Testi

\begin{tabular}{|l|l|r|}
\hline \multicolumn{2}{|l|}{ Kaiser-Meyer-Olkin Örnekleme Yeterliliğinin Ölçümü. } &, 921 \\
\hline Bartlett'in Sphericity Testi & Yaklaşı Ki-Kare & 1328,858 \\
\hline & Df & 91 \\
\cline { 2 - 3 } & Sig. &, 000 \\
\hline
\end{tabular}

Tablo 4. Temel Bileşenler Analizi

\begin{tabular}{|c|c|c|c|c|c|c|}
\hline \multirow{2}{*}{ Bileşen } & \multicolumn{3}{|c|}{ Başlangıç Özdeğerleri } & \multicolumn{3}{c|}{ Kare Yüklemelerin Ekstraksiyon } \\
\cline { 2 - 7 } & Toplam & $\begin{array}{c}\text { Varyansın } \\
\text { Yüzdesi }\end{array}$ & $\begin{array}{c}\text { Birikimli } \\
\text { Yüzde }\end{array}$ & Toplam & $\begin{array}{c}\text { Varyansın } \\
\text { Yüzdesi }\end{array}$ & $\begin{array}{c}\text { Birikimli } \\
\text { Yüzde }\end{array}$ \\
\hline $\mathbf{1}$ & 7,731 & 55,225 & 55,225 & 7,731 & 55,225 & 55,225 \\
\hline $\mathbf{2}$ &, 952 & 6,798 & 62,022 & & & \\
\hline $\mathbf{3}$ &, 915 & 6,534 & 68,556 & & & \\
\hline $\mathbf{4}$ &, 644 & 4,601 & 73,157 & & & \\
\hline $\mathbf{5}$ &, 581 & 4,152 & 77,309 & & & \\
\hline $\mathbf{6}$ &, 552 & 3,942 & 81,251 & & & \\
\hline $\mathbf{7}$ &, 483 & 3,451 & 84,703 & & & \\
\hline $\mathbf{8}$ &, 446 & 3,186 & 87,889 & & & \\
\hline $\mathbf{9}$ &, 404 & 2,888 & 90,777 & & & \\
\hline $\mathbf{1 0}$ &, 365 & 2,607 & 93,384 & & & \\
\hline $\mathbf{1 1}$ &, 271 & 1,936 & 95,320 & & & \\
\hline $\mathbf{1 2}$ &, 261 & 1,865 & 97,185 & & & \\
\hline $\mathbf{1 3}$ &, 243 & 1,735 & 98,920 & & & \\
\hline $\mathbf{1 4}$ &, 151 & 1,080 & 100,000 & & & \\
\hline Ekstraksiyon Metodu: Temel Bileşen Analizi. & & \\
\hline
\end{tabular}

KMO ve Bartlett's testi faktör analizi yapabilmek için ön şartlardandır. KMO ve Bartlett's testinin anlamlı olması faktör analizine uygun olduğunu gösterir. Kaiser-Meyer-Olkin Measure of Sampling Adequacy (KMO) değeri .92'dir ve $0.92>0.60$ olduğu için istatistiki bakımdan anlamlıdır. Bartlett's testi Chi-Square değeri 1328,858 ve serbestlik derecesi 91 olup anlamlıdır $(\mathrm{p}=0.00, \mathrm{p}<0.05)$. Faktör analizinde 14 maddenin öz değeri 1 olacak şekilde temel bileşenler analizi öncelikli olmak üzere varimax eksen döndürmesi gerçekleştirilmiştir. Çalışma sonucu tek faktör elde edilmiştir ve bu faktör toplam varyansın \%55'ini açıklamaktadır. 
Tablo 5. Ortak Varyans Analizi

\begin{tabular}{|l|c|c|}
\hline Maddeler & Illk & Çıkarma \\
\hline 1. Benimle gurur duyulacak bir meslekte çalışacağım & 1,000 &, 618 \\
\hline 2. Kamu kadrosunda bir işte çalışacağım & 1,000 &, 449 \\
\hline 3. Yeteneklerimi gösterebileceğim bir işte çalışacağım & 1,000 &, 598 \\
\hline 4. Masa başı bir işte çalışacağım & 1,000 &, 441 \\
\hline 5. Beni sıkmayan bir işte çalışacağım & 1,000 &, 506 \\
\hline 6. Toplumda saygı duyulan bir meslekte çalışacağım & 1,000 &, 660 \\
\hline 7. Kazancı bol olan bir işte çalışacağım & 1,000 &, 663 \\
\hline 8. Yükselebilme imkânı olan bir işte çalışacağım & 1,000 &, 629 \\
\hline 9. Yapacağım işten zevk alacağım & 1,000 &, 732 \\
\hline 10. Yapacağım iş bana lüks bir hayat sunacak & 1,000 &, 463 \\
\hline 11. Yapacağım iş cinsiyetime uygun olacak & 1,000 &, 428 \\
\hline 12. Yapacağım iş özel yaşamıma engel olmayacak & 1,000 &, 551 \\
\hline 13. Seçeceğim meslek geleceğimi güven altına alacak & 1,000 &, 633 \\
\hline $\begin{array}{l}\text { 14. Aldığım eğitimi yeterli görmeyip bir üst eğitime devam } \\
\text { edeceğim }\end{array}$ & 1,000 &, 360 \\
\hline Ekstraksiyon Metodu: Temel Bileşen Analizi. & & \\
\hline
\end{tabular}

9. madde $\% 73$ oranı ile toplam faktörü şekillendirmede en çok etkileyen faktördür. 0.30 'un altında faktör yükü olmadığ 1 için çıkarılacak madde yoktur ${ }^{10}$

Tablo 6. Güvenilirlik Analizi

\begin{tabular}{|c|c|c|}
\hline Cronbach Alfa & $\begin{array}{c}\text { Cronbach Alfa Standart } \\
\text { Maddeler }\end{array}$ & Madde Sayısı \\
\hline, 936 &, 936 & 14 \\
\hline
\end{tabular}

Cronbach Alfa değeri 0,94'tür. 0,94>0,70 olduğu için ölçeğin oldukça güvenilir olduğunu söylenebilir.

Farklılık analizleri kapsamında; birbirinden bağımsız iki grubun veya örneklemin bağımlı bir değişkene göre ortalamalarının karşılaştırılarak, ortalamalar arasındaki farkın belirli bir güven düzeyinde anlamlı olup olmadığını test etmek için kullanılan Bağımsız örneklemler T testi kullanılmıştır. T Testine göre; cinsiyet, birinci ya da ikinci sınıf olma, birinci öğretim ya da ikinci öğretimde

10 Şener Büyüköztürk, Veri Analizi El Kitabı, Pegem Yayınları, Ankara, 2002 s.127. 
öğrenim görüyor olmak, meslek lisesi mezunu olmak ya da olmamak açısından anlamlı bir farklılık yoktur $(\mathrm{p}>0,05)$ Bu nedenle ilk dört hipotez reddedilmiştir.

Tablo 7. Değişkenlere Göre Bağımsız Örneklem T Testi

\begin{tabular}{|l|c|c|c|c|c|c|}
\hline \multicolumn{2}{|l|}{ Faktörler } & N & Ort. & Std. Sap. & t & P \\
\hline \multirow{2}{*}{ Cinsiyet } & Kadın & 89 & 3,63 & 0,88 & \multirow{2}{*}{0,58} & \multirow{2}{*}{0,57} \\
\cline { 2 - 5 } & Erkek & 64 & 3,72 & 0,99 & & \\
\hline \multirow{2}{*}{ Sınıf } & $\mathbf{1 .}$ & 71 & 3,68 & 0,90 & \multirow{2}{*}{0,22} & \multirow{2}{*}{0,82} \\
\cline { 2 - 6 } & $\mathbf{2 .}$ & 82 & 3,65 & 0,96 & & \\
\hline \multirow{2}{*}{ Öğrenim } & Örgün & 73 & 3,56 & 0,97 & \multirow{2}{*}{1,31} & \multirow{2}{*}{0,19} \\
\cline { 2 - 6 } & Gece & 80 & 3,76 & 0,88 & & \multirow{2}{*}{0,84} \\
\hline \multirow{2}{*}{ Lise } & Meslek & 75 & 3,60 & 0,87 & \\
\cline { 2 - 5 } & Diğer & 78 & 3,73 & 0,98 & & \\
\hline
\end{tabular}

${ }^{*} \mathrm{p}<0.01$ düzeyinde anlamlıdır.

Araştırmanın diğer hipotezleri için Tek Yönlü Varyans analizi (One-Way Anova) kullanılmıştır. Tek yönlü varyans analizi, bağımsız üç veya daha fazla örneklem ortalaması arasındaki farkın sıfırdan anlamlı bir şekilde farklı olup olmadığını test etmek üzere uygulanır. Farklılık olan verilerde farklılığın hangi gruplardan kaynaklandığını belirlemek için post-hoc testlerinden LCD testi kullanılmıştır. Anova tablosundan kardeş sayısının öğrencilerin gelecek beklentilerine etki ettiği görülmüştür. Dolayısıyla, grupların kardeş sayısı arasında anlamlı bir farklılık olduğu bulunmuştur $(\mathrm{F}=1.35, \mathrm{p}<.005)$.Farklılığın hangi gruplar arasında olduğunu görmek için yapmış olduğumuz LCD testine göre farklılık olan grup 1 kardeşi olanlar ile 4 ve 4 'ten fazla kardeşi olanlar arasında, 4 ve üzeri kardeşi olanlar lehinedir. Ortalamalara baktığımızda 4 ve üzeri kardeşi olanların beklenti düzeylerinin (ort=3,85) 1 kardeşi olanlardan(ort=3,36) yüksek olduğu görülmektedir.

Tablo 8. Kardeşler arasında ANOVA Sonuçları

\begin{tabular}{|l|c|c|c|c|c|}
\hline Varyansın Kaynağı & Kareler Toplamı & sd & Kareler Ortalaması & F & p \\
\hline Gruplararası & 4,630 & 4 & 1,158 & 1,354 &, 025 \\
\hline Gruplariçi & 126,542 & 148 &, 855 & & \\
\hline Toplam & 131,172 & 152 & & & \\
\hline
\end{tabular}


Tablo 9. Kardeş Sayısına Göre Ortalamalar

\begin{tabular}{|l|c|c|c|}
\hline Kardeş Sayısı & N & Ort. & Std. Sap. \\
\hline yok & 2 & 3,0714 &, 80812 \\
\hline $\mathbf{1}$ & 25 & 3,3600 &, 84979 \\
\hline $\mathbf{2}$ & 38 & 3,7293 & 1,07575 \\
\hline $\mathbf{3}$ & 48 & 3,6443 & 1,00363 \\
\hline $\mathbf{4}$ ve üzeri & 40 & 3,8536 &, 68683 \\
\hline Total & 153 & 3,6662 &, 92896 \\
\hline
\end{tabular}

Ailenin gelirine göre Anova testi sonuçlarına baktığımızda farklılığın anlamlı olduğunu görüyoruz $(\mathrm{p}<0,05)$. Farklılığın nedeninin hangi gruplar arasında olduğunu görmek için post-hoc testlerinden LCD testi yapıldı. Farklılık 1000-1500 gelire sahip grupla; 2001-2500, 2501-3000, 3001 ve üzeri gruplar arasında oluşmuştur. Grup ortalamalarına baktığımızda geleceğe dair beklentilerinin gelirler artıkça arttığı görülmektedir.

Tablo 10. Aile Gelirine Göre Anova Testi

\begin{tabular}{|l|c|c|c|c|c|}
\hline $\begin{array}{l}\text { Varyansın } \\
\text { Kaynağı }\end{array}$ & Kareler Toplamı & sd & Kareler Ortalaması & F & p \\
\hline Gruplararası & 16,872 & 4 & 4,218 & 5,461 &, 000 \\
\hline Gruplariçi & 114,300 & 148 &, 772 & & \\
\hline Toplam & 131,172 & 152 & & & \\
\hline
\end{tabular}

Tablo 11. Aile Geliri Ortalamaları

\begin{tabular}{|l|c|c|c|}
\hline Aile Geliri & Sayı & Ortalama & Std. Sapma \\
\hline $\mathbf{1 0 0 0 - 1 5 0 0}$ & 51 & 3,3375 & 1,03402 \\
\hline $\mathbf{1 5 0 1 - 2 0 0 0}$ & 44 & 3,5016 &, 85082 \\
\hline $\mathbf{2 0 0 1 - 2 5 0 0}$ & 19 & 4,0000 &, 72921 \\
\hline $\mathbf{2 0 0 1 - 3 0 0 0}$ & 20 & 4,0821 &, 54903 \\
\hline $\mathbf{3 0 0 1}$ ve üzeri & 19 & 4,1579 &, 89486 \\
\hline Total & 153 & 3,6662 &, 92896 \\
\hline
\end{tabular}


Öğrencilerin ailelerinin yaşadığı yere göre yapılan Anova testine göre, yaşanılan yerler bakımından grup ortalamaları anlamlı farklılık göstermektedir $(\mathrm{p}<0,05)$. Farklılığın nedeninin hangi gruplar arasında olduğunu anlamak için LCD testine baktığımızda köyde yaşayanlar ile ve ilçede yaşayanlar arasında farklılık olduğu görülmektedir. Grup ortalamalarına baktığımızda, köyde yaşayanların gelecek beklentileri ilçe ve ilde yaşayanlardan fazla olup, ailesi ilçede yaşayanların anlamlı farklılık olmasa bile, ilde yaşayanlardan daha yüksek beklenti düzeyine sahip olduğu görülmektedir.

Tablo 12. Ailenin Yaşadığı Yere Göre Anova Testi

\begin{tabular}{|l|c|c|c|c|c|}
\hline Varyansın Kaynağı & Kareler Toplamı & Sd & Kareler Ortalaması & $\mathbf{F}$ & $\mathbf{p}$ \\
\hline Gruplararası & 6,418 & 2 & 3,209 & 3,859 &, 023 \\
\hline Gruplariçi & 124,753 & 150 &, 832 & & \\
\hline Toplam & 131,172 & 152 & & & \\
\hline
\end{tabular}

Tablo 13. Ailenin Yaşadığı Yere Göre Ortalamalar

\begin{tabular}{|l|c|c|c|}
\hline Yaşanılan Yer & N & Ortalama & Std. Sap. \\
\hline köy & 24 & 4,1339 &, 75690 \\
\hline ilçe & 45 & 3,6317 &, 92305 \\
\hline il & 84 & 3,5510 &, 94479 \\
\hline Total & 153 & 3,6662 &, 92896 \\
\hline
\end{tabular}

Öğrencilerin öğrenim görürken konakladıkları yere göre yapılan tek yönlü ANOVA testine göre gruplar arasında anlamlı bir farklılık yoktur. Ancak farklılık anlamlı olmamakla birlikte en yüksek beklentiye sahip öğrenciler, evde arkadaşları ile yaşayanlar (ort=3,97) iken; en az beklentiye sahip öğrenciler, aileleriyle birlikte yaşayanlar (ort=3,56)'dır.

Tablo 14. Yaşanılan Yere Göre Anova Testi

\begin{tabular}{|l|c|c|c|c|c|}
\hline Varyansın Kaynağı & Kareler Toplamı & sd & Kareler Ortalaması & F & p \\
\hline Gruplararası & 3,034 & 3 & 1,011 & 1,176 &, 321 \\
\hline Gruplariçi & 128,138 & 149 &, 860 & & \\
\hline Toplam & 131,172 & 152 & & & \\
\hline
\end{tabular}


Tablo 15. Yaşanılan Yere Göre Ortalamalar

\begin{tabular}{|l|c|c|c|}
\hline Bir. Yaşam. & Sayı & Ortalama & Std. Sapma \\
\hline Ailemle & 88 & 3,5560 &, 86358 \\
\hline Yurtta & 45 & 3,7889 &, 92606 \\
\hline Evde(tek) & 6 & 3,6548 & 1,53690 \\
\hline Evde(ark) & 14 & 3,9694 & 1,02700 \\
\hline Total & 153 & 3,6662 &, 92896 \\
\hline
\end{tabular}

\section{Sonuç ve Tartışma}

Çalışmadan elde edilen sonuçlara göre; çağrı merkezi hizmetleri bölümü öğrencilerinin yarısından fazlasının kız öğrencilerden oluştuğu söylenebilir (\%58). Normal öğretim öğrencilerin ikinci öğretimden (\%52) diğer liselerden mezun olanların meslek lisesinden fazla (\%51) olduğu görülmektedir. Ailelerinin yaşadığı yerlere göre olan sınıflandırmada en fazla ilde yaşayanların (\%55) olduğu, ilçede yaşayanların ikinci sırada (\%30) en az ise köyde yaşayanların olduğu görülmektedir (\%16). Çağrı Merkezi Hizmetleri bölümü öğrencilerinin yarısından fazlasının ailesiyle yaşadığını (\%58) söyleyebiliriz. \%27'sinin yurtta yaşadığını, \%9'unun evde arkadaşlarıyla ve \%4'ünün evde tek başına yaşadığını görüyoruz. Aile gelirine göre yapılan sinıflandırmada en büyük grubun \%33 ile 1000-1500 arasında olduğu söylenebilir. 1501-2000 arasında gelire sahip grup $\% 30,2001-2500$ gelire sahip grup \%12, 2501-3000 gelire sahip olanlar \%13, 3000 ve üzeri gelire sahip olanlar ise $\% 12^{\prime}$ lik dilimi oluşturmaktadır.

Öğrenciler yaptıkları işten zevk almayı ve yükselebilecekleri bir işte çalışmayı en çok önemsemişlerdir. Ardından saygı duyulan bir meslekte çalışmaya ve kendilerini sıkmayan bir işte çalışmaya önem verdiklerini görüyoruz. En az önemsedikleri madde ise yapacakları işin onlara lüks bir hayat sunmasıdır. Gençler işlerinden zevk almayı, saygı duyulmayı, kendilerini sıkmayacak bir işte çalışıyor olmayı lüks bir hayata tercih etmektedirler.

Tuncer (2011) $)^{11}$, Üzüm ve Uçkun (2015) $)^{12}$ yükseköğrenim öğrencilerine yönelik yaptıkları çalışmalarda kız öğrencilerin beklenti düzeyleri ile erkek öğrencilerin beklenti düzeyleri arasında yalnızca kız öğrenciler lehine anlamlı

11 Murat Tuncer, A.g.e.

12 Burcu Üzüm, Seher Uçkun, "Büro Yönetimi Ve Yönetici Asistanlığı Öğrencilerinin Demografik Özellikleri İle Kariyer Geleceği Beklentilerinin Ölçülmesi: Kocaeli MYO Örneği”, Elektronik Mesleki Gelişim ve Araştırma Dergisi, Mayıs, sayı 3, 2015, 71-80. 
farklılık bulgulamalarına rağmen, çalışmada; cinsiyete, sınıfa, öğretim durumuna, mezun olunan liseye göre anlamlı farkl1lık görülmemiştir. Dolayısıyla ilk dört hipotez reddedilmiştir.

Ailenin gelirine göre yapılan varyans analizinde farkl1lı 1000-1500 gelire sahip grupla; 2001-2500, 2501-3000, 3001 ve üzeri gruplar arasında oluşmuştur. Ailesi en az gelire sahip grup en az beklentiye sahiptir. Ayrıca grup ortalamalarına baktı̆̆ımızda öğrencilerin geleceğe dair beklentilerinin gelirleri artıkça arttığını görüyoruz. Hipotez 5 desteklenmiştir. Tuncer (2011) ve Üzüm ve Uçkun (2015) çalışmalarında öğrencilerin gelir durumuna göre beklenti düzeylerinde istatistiki olarak anlamlı farkl11ık yoktur.

Ailelerinin yaşadığı yere göre yapılan Anova testine göre köyde yaşayanlar ile il ve ilçede yaşayanlar arasında farklılık olduğu görülmektedir. Grup ortalamalarına bakıldığında, köyde yaşayanların gelecekten beklentileri ilçe ve ilde yaşayanlardan fazladır. Ayrıca yerleşim yeri büyüdükçe beklenti azalmaktadır. $\mathrm{Bu}$ durumda küçük yerde yaşayanların büyük yerde yaşayanlara göre gelecekten daha fazla beklenti içinde olduğu söylenebilir. Hipotez 6 desteklenmiştir. Ayrıca ailesi ile yaşayanların ve ilde yaşayanların yüzdesi \%50'nin üzerinde olduğu için öğrencilerin yarısından fazlasının Konya'da yaşadığı söylenebilir. Konya'da aileleriyle yaşayan özellikle meslek lisesi mezunu gençler sınavsız geçişin de etkisiyle üniversiteyi daha farklı algılamaktadırlar. Sınavsız geçişin kaldırılmasından dolayı, önümüzdeki senelerde öğrenim gören öğrencilerin gelecek beklentilerinin artıp artmadığı benzeri çalışmalarla ölçülebilir.

Öğrenciler, konakladıkları yer açısından incelendiğinde, istatistiki olarak anlamlı farklılık oluşmamıştır. En büyük beklentiye sahip grup evde arkadaşları ile yaşayanlar iken, en az beklentiye sahip grup ailesiyle birlikte yaşayanlardadır. Hipotez 7 reddedilmiştir.

1 kardeşe sahip öğrenciler ile 4 ve daha fazla kardeşe sahip öğrenciler arasında istatistiki olarak anlamlı farklı1ık bulunmaktadır. Buna göre, 8. Hipotez desteklenmiştir. Kardeş sayısı arttıkça genel olarak (2 ve 3 kardeş hariç) öğrencilerin beklentileri artmaktadır. En büyük beklenti dört ve daha fazla kardeşi olan öğrencilerdedir. Tuncer (2011)'de 3-4 kardeş ile 5 ve fazla kardeş arasında anlamlı farkl11ık bulmuştur.

Çalışma 2016-2017 yılında Selçuk Üniversitesi Çağrı Merkezi Hizmetleri bölümünde öğrenim gören öğrenciler ve Konya ili ile sınırlıdır. Daha farklı şehir ve bölümlerde yapılacak çalışmalar ile karşılaştırma yapılabilmesi ve meslek yüksekokulunda öğrenim gören gençlerin gelecek beklentileri hakkında fikir vermesi açısından önemlidir. 


\section{Kaynakça}

Adler, A., İnsan Tabiatını Tanıma, çev. Ayda Yörükan, Ankara, Türkiye İş Bankası Yayınları, 1994.

Apak, H., "Suriyeli Göçmenlerin Gelecek Beklentileri", Birey ve Toplum Sosyal Bilimler Dergisi, 5(1), 2015.

Büyüköztürk, Ş., Veri Analizi El Kitabı, Ankara, Pegem Yayınları, 2002.

Çokluk, Ö., Örgütlerde Tükenmişlik: Yönetimde Çă̆daş Yaklaşımlar, ed. Cevat Elma, Kamile Demir, Ankara, Anı Yayıncılık, 2000.

Güler, M., "Üniversiteli ve İşçi Gençliğin Gelecek Beklentileri ve Kötümserlik İyimserlik Düzeyleri”, Kriz Dergisi, 6 (1), 1998.

İnceoğlu, M., Güdüleme Yöntemleri, Ankara, 1985.

Şanl1, T. - Saraçl1, S., "Analysis Of The Factors Effecting The University Students' Future Expectations", The Journal of KAU IIBF, 6(11), 2015.

Tuncer, M., "Yükseköğretim Gençliğinin Gelecek Beklentileri Üzerine Bir Araştırma, Turkish Studies-International Periodical for the Languages", Literature and History of Turkish or Turkic, 6(2), 2011.

Üzüm, B. - Uçkun, S., "Büro Yönetimi Ve Yönetici Asistanlığı Öğrencilerinin Demografik Özellikleri İle Kariyer Geleceği Beklentilerinin Ölçülmesi: Kocaeli MYO Örneği”, Elektronik Mesleki Gelişim ve Araştırma Dergisi, sayı 3, May1s 2015.

http://www.tdk.gov.tr/index.php?option=com_gts\&kelime=BEKLENT\%$\mathrm{C} 4 \% \mathrm{~B} 0$. 